\title{
PENGARUH ENTREPRENEURIAL ORIENTATION, CULTURE ORGANIZATION INTERNAL FACTOR TERHADAP PERFORMANCE ORGANIZATION MELALUI CORPORATE ENTREPRENUERSHIP CAPABILITY PADA UMKM BATIK TULIS DI JAWA TIMUR
}

\author{
Nur Hidayati ${ }^{1}$ \\ * Fakultas Ekonomi Universitas Slamet Riyadi Surakarta \\ *nufhanur@gmail.com ${ }^{l}$ \\ Fadjar Harimurti ${ }^{2}$ \\ * Fakultas Ekonomi Universitas Slamet Riyadi Surakarta \\ *fadjarharimurti@gmail.com ${ }^{2}$ \\ Dewi SPA ${ }^{3}$ \\ * Fakultas Ekonomi Universitas Slamet Riyadi Surakarta \\ *dewi.astuti@gmail.com ${ }^{3}$
}

\begin{abstract}
This study aimed to analyze the effect quality of information system and quality of information on user satisfaction of e-filing system. The object of the research is conducted at the Tax Services Office (KPP) Pratama Karanganyar, using sample of 100 respondent with purposive sampling technique. Collecting data using questionnaire techniques, data analysis techniques using multiple linear regression analysis. The conclusion of each hypothesis test results show that (1) quality of information system have significant effect on user satisfaction of e-filing system. (2) quality of information have significant effect on user satisfaction of e-filing system. Implication of this study, increased the quality of information system and quality of information can influencing increased on user satisfaction of e-filing system.
\end{abstract}

Keywords: quality of information system, quality of information, user satisfaction of e-filing system

\section{Pendahuluan}

Kualitas pelayanan publik sampai saat ini masih menjadi isu sentral yang ditandai dengan perilaku inefisiensi dari aparat, prosedur berbelit-belit, serta tidak adanya kepastian waktu, sehingga faktorfaktor tersebut dapat menjadi penghambat dalam mewujudkan good government. Berdasarkan pernyataan Keputusan Menteri Pendayagunaan Aparatur Negara No. 25 Tahun 2004 Bab Pendahuluan dinyatakan sebagai berikut:

Pelayanan publik oleh aparatur pemerintah dewasa ini masih banyak dijumpai kelemahan sehingga belum dapat memenuhi kualitas yang diharapkan masyarakat. Hal ini ditandai dengan masih adanya berbagai keluhan masyarakat yang disampaikan melalui media massa, sehingga dapat menimbulkan citra yang kurang baik terhadap aparatur pemerintah. Mengingat fungsi utama pemerintah adalah melayani masyarakat maka pemerintah perlu terus berupaya meningkatkan kualitas pelayanan (Kep. Menpan No. 25 Tahun 2004).

Upaya perbaikan pelayanan publik melalui reformasi birokrasi telah dilakukan pemerintah dalam berbagai aspek, dan salah satunya adalah mengoptimalkan pelayanan publik dengan memanfaatkan sistem berbasis internet. Reformasi birokrasi melalui pemanfaatan internet dan teknologi informasi telah mulai banyak diterapkan seperti $e$ paspor, PSB-Online, Samsat-online, BPJS-online, ePaspor, e-Procurement, dan sebagainya. Penggunaan teknologi informasi dalam bidang perpajakan telah dilakukan oleh Direktorat Jenderal Pajak (DJP), salah satu bentuk pengembangan sistem perpajakan diantaranya adalah sistem e-filing.

Secara umum, e-Filing melalui situs Direktorat Jenderal Pajak (DJP), beralamatkan di 
www.pajak.go.id, adalah sistem pelaporan SPT menggunakan sarana internet tanpa melalui pihak lain dan tanpa biaya apapun, yang dibuat oleh DJP untuk memberikan kemudahan bagi WP dalam pembuatan dan penyerahan laporan SPT kepada DJP secara lebih mudah, lebih cepat, dan lebih murah. Dengan e-Filing, WP tidak perlu lagi menunggu antrian panjang di lokasi Dropbox maupun Kantor Pelayanan Pajak (KPP). Hal ini merupakan salah satu terobosan baru pelaporan SPT yang digulirkan DJP untuk membuat WP semakin mudah dan nyaman dalam melaksanakan kewajiban perpajakannya (http://pajak.go.id).

Implementasi sistem e-filing memiliki kontribusi positif terhadap peningkatan pelayanan prima kepada wajib pajak. Sebelum sistem e-filing diimplementasikan, wajib pajak harus datang ke Kantor Pelayanan Pajak dan dengan adanya penerapan sistem e-filing maka wajib pajak akan memperoleh informasi perpajakan dengan cepat dan mudah.

Kesuksesan atau kegagalan penerapan sistem $e$ filing memotivasi peneliti untuk melakukan riset pada Kantor Pelayanan Pajak (KPP) Pratama di Kabupaten Karanganyar. Kontribusi yang diharapkan dari penelitian ini untuk memberikan implikasi stratejik bagi KPP Pratama Karanganyar dalam upaya meningkatkan kepuasan pengguna sistem e-filing. Pokok permasalahan dalam penelitian ini, karena belum pernah ada penelitian yang melakukan evaluasi terhadap kesuksesan sistem e-filing di Kantor KPP Pratama Kabupaten Karanganyar, di mana kepuasan pengguna merupakan indikator penting dari keberhasilan penerapan sistem.

\section{Kajian Pustaka dan Pengembangan Hipotesis}

Teori keberhasilan sistem informasi ( $D \& M$ Information System Success Model) yang dikembangkan DeLone \& McLean (1992) telah banyak diadopsi dalam berbagai riset sebagai kriteria dasar untuk mengevaluasi kesuksesan sistem informasi. Menurut model $D \& M$, kesuksesan sistem informasi dapat dinilai dari user satisfaction (kepuasan pengguna) dari suatu sistem informasi, sedangkan kepuasan pengguna ditentukan dari persepsi pengguna terhadap kualitas sistem dan kualitas informasi.

Hasil penelitian yang dilakukan oleh Istianingsih \& Utami (2009); Purwaningsih (2010);
Alhendawi \& Baharudin (2013); Raminda \& Ardini (2014); Fendini dkk (2014); Djuhono Tan dkk (2015); Setyo \& Rahmawati (2015); Sharabati et al (2015); Kartika dkk (2016) menunjukkan bahwa kepuasan pengguna sistem informasi dapat diukur dari seberapa baik kualitas sistem dan kualitas informasi mampu memberikan kemudahan dan manfaat bagi pengguna sistem dalam mendukung pelaksanaan tugas. Implikasinya, apabila kualitas sistem dan kualitas informasi semakin baik, akan meningkatkan kepuasan pengguna sistem.

Implementasi sistem e-filing pada Kantor Pelayanan Pajak (KPP) Pratama Kabupaten Karanganyar dengan maksud untuk memudahkan dan mengoptimalisasikan pelayanan kepada Wajib Pajak. Fokus model penelitian ini untuk mengevaluasi apakah sistem e-filling yang diterapkan di KPP Pratama Karanganyar memiliki kualitas sistem dan kualitas informasi yang baik sehingga mampu memuaskan para wajib pajak selaku penggguna sistem. Kontribusi yang diharapkan dari penelitian ini dapat menjadi bahan evaluasi bagi KPP Pratama Karanganyar untuk perbaikan terhadap permasalahan yang terjadi dalam penerapan sistem $e$-filing, sehingga diharapkan dapat menjadi proyek yang berhasil dan berkelanjutan.

Permasalahan penelitian ini, apakah kualitas sistem berpengaruh signifikan terhadap kepuasan pengguna sistem e-filing pada wajib pajak di KPP Pratama Karanganyar, apakah kualitas informasi berpengaruh signifikan terhadap kepuasan pengguna sistem e-filing pada wajib pajak di KPP Pratama Karanganyar.

Hipotesis yang diajukan dalam penelitian ini, kualitas sistem berpengaruh signifikan terhadap kepuasan pengguna sistem $e$-filing pada wajib pajak di KPP Pratama Karanganyar, kualitas informasi berpengaruh signifikan terhadap kepuasan pengguna sistem e-filing pada wajib pajak di KPP Pratama Karanganyar.

\section{Metode Penelitian}

\section{Desain Penelitian}

Jenis penelitian ini adalah penelitian survey dengan menggunakan pendekatan kuantitatif, di mana analisis data yang dilakukan dalam penelitian ini dengan melakukan perhitungan statistik. Desain/rancangan penelitian ini adalah tipe 
eksplanatori yaitu menjelaskan hubungan kausal antara variabel-variabel melalui pengujian hipotesis.

\section{Objek Penelitian}

Objek penelitian ini adalah Kantor Pelayanan Pajak (KPP) Pratama Karanganyar.

\section{Populasi dan Sampel}

Populasi penelitian ini adalah seluruh wajib pajak orang pribadi di wilayah Kabupaten Karanganyar. Dalam populasi yang tidak diketahui jumlahnya secara pasti, maka sampel yang diambil tergantung pada besarnya tingkat signifikansi dan kesalahan (error) yang diharapkan. Untuk menentukan ukuran sampel penelitian digunakan rumus Leedy yaitu:

$$
\begin{aligned}
N & =\left(\frac{Z}{e}\right)^{2}(P)(1-P) \\
& =\left(\frac{1,96}{0,1}\right)^{2} \times 0,25 \\
& =96,04 \\
& =96 \text { (pembulatan) }
\end{aligned}
$$

Dari hasil tersebut sampel dalam penelitian ini diambil sebanyak 96 responden, namun untuk memudahkan peneliti dalam melakukan penelitian, maka sampel diambil sebanyak 100 responden. Pengambilan sampel dilakukan dengan teknik purposive sampling, yaitu Wajib Pajak orang pribadi yang sudah pernah menggunakan sistem e-filing di KPP Pratama Karanganyar dalam melaporkan kewajiban perpajakannya sampai pada bulan Maret 2017.

\section{Instrumen Penelitian}

Penelitian ini menggunakan tiga instrumen, kuesioner kualitas sistem diukur dengan lima indikator yaitu ease of use, system flexibility, kecepatan akses (response time), reliability, dan security (DeLone \& McLean dalam Radityo \& Zulaikha, 2007: 12). Kualitas informasi diukur dengan lima indikator yang dikembangkan oleh Pitt \& Watson dalam Radityo \& Zulaikha (2007: 12) yaitu completeness, relevance, accuracy, timeliness, dan format. Kepuasan pengguna diukur dengan enam item berdasarkan perasaan

Riset Akuntansi dan Keuangan Indonesia, 2(2), 2017 pengguna setelah membandingkan antara hasil atau kinerja layanan dengan harapan (Kotler, 2001: 36) dengan indikator kesesuaian harapan dengan kenyataan,. pilihan yang tepat, merasa senang, merasa keputusan sudah benar.

\section{Teknik Pengumpulan Data}

Teknik pengumpulan data menggunakan kuesioner yang diukur dengan skala Likert 5 poin dengan item pernyataan positif.

\section{Pengujian Data}

Untuk menguji kualitas data dilakukan uji validitas dan reliabilitas instrumen menggunakan rumus Korelasi Pearson dan Cronbach Alpha.

\section{Teknik Analisis Data}

1. Uji Asumsi Klasik

Uji Asumsi Klasik dilakukan melalui empat uji yaitu uji multikolinieritas, uji autokorelasi, uji heteroskedastisitas, dan uji normalitas.

2. Teknik analisis data

Analisis regresi linier berganda bertujuan untuk mengetahui pengaruh kualitas sistem dan kualitas informasi terhadap kepuasan pengguna sistem $e$ filling, dinyatakan dengan persamaan sebagai berikut (Sugiyono, 2008: 221):

$$
\begin{aligned}
& \mathrm{KP}=\alpha+\beta_{1}+\beta_{1} \mathrm{KS}+\beta_{2} \mathrm{KI}+\mathrm{e} \\
& \text { Keterangan: } \\
& \mathrm{KP} \text { : Kepuasan pengguna sistem } e \text {-filling } \\
& \text { KS : Kualitas sistem informasi } \\
& \text { KI : Kualitas informasi } \\
& \alpha \quad \text { : konstanta } \\
& \beta_{1} \ldots \beta_{2} \quad \text { : Koefisien regresi } \\
& \text { e : Standar erro }
\end{aligned}
$$

3. Pengujian Hipotesis

Pengujian hipotesis dilakukan melalui uji t. Kriteria pengujian: apabila $p$ value $<0,05$ maka Ho ditolak berarti kualitas sistem informasi dan kualitas informasi berpengaruh signifikan secara parsial terhadap kepuasan pengguna sistem $e$ filling. Sebaliknya apabila $p$ value $\geq 0,05$ maka Ho diterima berarti kualitas sistem informasi dan kualitas informasi tidak berpengaruh signifikan secara parsial terhadap kepuasan pengguna sistem e-filling

4. Uji F bertujuan untuk menguji ketepatan model regresi linier berganda dalam memprediksi pengaruh kualitas sistem informasi dan kualitas 
informasi terhadap kepuasan pengguna sistem $e$ filling

Uji koefisien determinasi bertujuan mengetahui persentase sumbangan pengaruh kualitas sistem informasi dan kualitas informasi terhadap kepuasan pengguna sistem $e$-filling

\section{Hasil dan Pembahasan Karakteristik Demografi}

Karakteristik demografi responden dalam penelitian ini disajikan seperti tabel berikut.

Tabel 1: Karakteristik Responden

\begin{tabular}{|c|c|c|c|}
\hline Karakteristik & Keterangan & $\begin{array}{l}\text { Jumlah } \\
\text { (orang) }\end{array}$ & $\begin{array}{c}\text { Persentase } \\
(\%)\end{array}$ \\
\hline \multicolumn{4}{|l|}{ Jenis } \\
\hline \multirow[t]{3}{*}{ Kelamin } & Laki-laki & 63 & 63,00 \\
\hline & Perempuan & 37 & 37,00 \\
\hline & Total & 100 & 100 \\
\hline Tingkat & SD & 0 & 0,00 \\
\hline \multirow[t]{6}{*}{ Pendidikan } & SMP & 3 & 3,00 \\
\hline & SMA & 33 & 33,00 \\
\hline & Diploma (D1/D2/D3) & 18 & 18,00 \\
\hline & Sarjana (S1) & 39 & 39,00 \\
\hline & Sarjana (S2) & 7 & 7,00 \\
\hline & Total & 100 & 100 \\
\hline Jenis & PNS & 13 & 13,00 \\
\hline \multirow[t]{4}{*}{ Pekerjaan } & TNI/Polri & 2 & 2,00 \\
\hline & Pegawai Swasta & 27 & 27,00 \\
\hline & Pedagang/wiraswasta & 58 & 58,00 \\
\hline & Total & 100 & 100 \\
\hline Penghasilan & $<$ Rp. 1.500 .000 & 5 & 5,00 \\
\hline \multirow[t]{3}{*}{ Per bulan } & Rp. 1.500 .000 - Rp. 3.000 .000 & 33 & 33,00 \\
\hline & $>$ Rp. 3.000 .000 & 62 & 62,00 \\
\hline & Total & 100 & 100 \\
\hline
\end{tabular}

\section{Hasil Uji Validitas dan Reliabilitas Instrumen}

Hasil uji validitas item untuk variabel kualitas sistem informasi, kualitas informasi, dan kepuasan pengguna sistem $e$-filing melalui uji Korelasi Pearson menunjukkan bahwa semua item pernyataan valid, ditunjukkan $p$ value $<0,05$. Hasil uji validitas untuk variabel kualitas sistem informasi, kualitas informasi, dan kpuasan pengguna sistem $e$-filing disajikan seperti tabel berikut.
Tabel 2: Hasil Uji Validitas

\begin{tabular}{cccccc}
\hline & \multicolumn{5}{c}{$p$ value } \\
\cline { 2 - 5 } No & Kualitas & $\begin{array}{c}\text { Kualitas } \\
\text { Item }\end{array}$ & $\begin{array}{c}\text { Kepuasan } \\
\text { Pengguna } \\
\text { Informasi }\end{array}$ & $\alpha$ & Kesimpulfan \\
& Informasi & $\begin{array}{c}\text { Sistem } e \\
\text { filing }\end{array}$ & & \\
\hline 1 & 0,000 & 0,000 & 0,000 & 0,05 & Valid \\
2 & 0,000 & 0,000 & 0,000 & 0,05 & Valid \\
3 & 0,000 & 0,000 & 0,000 & 0,05 & Valid \\
4 & 0,000 & 0,000 & 0,000 & 0,05 & Valid \\
5 & 0,000 & 0,000 & 0,000 & 0,05 & Valid \\
6 & & & 0,000 & 0,05 & Valid \\
\hline
\end{tabular}

Berdasarkan uji reliabilitas instrumen diperoleh hasil bahwa instrumen untuk variabel kualitas sistem informasi, kualitas informasi, dan kepuasan pengguna sistem e-filing dinyatakan reliabel karena masingmasing variabel menghasilkan Cronbach Alpha > 0,60. Hasil uji reliabilitas untuk variabel kualitas sistem informasi, kualitas informasi, dan kpuasan pengguna sistem e-filing disajikan seperti tabel berikut.

Tabel 3: Hasil Uji Reliabilitas Instrumen

\begin{tabular}{lccc}
\hline \multicolumn{1}{c}{ Variabel } & Cronbach Alpha & Kriteria uji Kesimpulan \\
\hline Kualitas sistem & & & \\
informasi & 0,715 & 0,60 & Reliabel \\
$\begin{array}{l}\text { Kualitas informasi } \\
\text { Kepuasan pengguna }\end{array}$ & 0,824 & 0,60 & Reliabel \\
\begin{tabular}{l} 
sistem $\quad$ e-filing \\
\hline
\end{tabular} & 0,905 & 0,60 & Reliabel \\
\hline
\end{tabular}

\section{Hasil Uji Asumsi Klasik}

Hasil uji asumsi klasik menunjukkan bahwa model regresi linier berganda tidak terjadi masalah multikolinieritas, tidak terjadi masalah heteroskedastisitas, tidak terjadi masalah autokorelasi, dan residual normal. Hasil uji asumsi klasik disajikan seperti tabel berikut. 
Tabel 4: Hasil Uji Asumsi Klasik

\begin{tabular}{lll}
\hline Uji Asumsi Klasik & \multicolumn{1}{c}{ Hasil Uji } & \multicolumn{1}{c}{ Kesimpulan } \\
\hline Uji & Tolerance $(0,968 ;$ & Tidak ada multikolinieritas \\
Multikolinieritas & $0,968)>0,1$ & \\
& VIF $(1,033 ;$ & \\
& $1,033)<10$ & \\
& $P$ value $(0,070)>$ & Tidak ada Autokorelasi \\
Uji Autokorelasi & 0,05 & \\
& $P$ value $(0,571 ;$ & Tidak ada \\
Uji & $0,242)>0,05$ & Heteroskedastisitas \\
Heteroskedastisitas & $P$ value $(0,908)>$ & Residual normal \\
Uji Normalitas & 0,05 & \\
& & \\
\hline
\end{tabular}

\section{Hasil Analisis Regresi Linier Berganda}

Hasil analisis regresi linier berganda dengan program SPSS versi 20 disajikan seperti tabel berikut.

Tabel 5: Hasil Analisis Regresi Linier Berganda

\begin{tabular}{lccc}
\hline Variabel Independen & $\begin{array}{c}\text { Koefisien } \\
\text { regresi }\end{array}$ & Nilai t & Signifikansi \\
\hline $\begin{array}{l}\text { Konstanta } \\
\begin{array}{l}\text { Kualitas sistem } \\
\text { informasi }\end{array}\end{array}$ & 9,783 & & \\
\hline Kualitas informasi & 0,328 & 2,743 & $0,001^{*}$ \\
\hline $\mathrm{F}: 19,357$ & 5,470 & 5,000 & $0,000^{*}$ \\
Adjusted $\mathrm{R}^{2}: 0,271$ & & & 0,000 \\
\hline \multicolumn{1}{l}{ Variabel dependen: Kepuasan pengouna sistem e-filing }
\end{tabular}

\section{Pengujian Hipotesis}

1. Uji pengaruh kualitas sistem informasi terhadap kepuasan pengguna sistem $e$-filing

Hasil uji pengaruh kualitas sistem informasi terhadap kepuasan pengguna sistem e-filing diperoleh nilai $\mathrm{t}$ hitung sebesar 2,743 dengan $p$ value $(0,007)<0,05$ berarti kualitas sistem informasi berpengaruh signifikan terhadap kepuasan pengguna sistem e-filing. Dengan demikian hipotesis 1 yang menyatakan "Kualitas sistem informasi berpengaruh signifikan terhadap kepuasan pengguna sistem e-filing pada wajib pajak di KPP Pratama Karanganyar" diterima atau terbukti kebenarannya.

2. Uji pengaruh kualitas informasi terhadap kepuasan pengguna sistem $e$-filing
Hasil uji pengaruh kualitas informasi terhadap kepuasan pengguna sistem $e$-filing diperoleh nilai t hitung sebesar 5,000 dengan $p$ value $(0,000)<$ 0,05 berarti kualitas informasi berpengaruh signifikan terhadap kepuasan pengguna sistem $e$ filing. Dengan demikian hipotesis 2 yang menyatakan "Kualitas informasi berpengaruh signifikan terhadap kepuasan pengguna sistem $e$ filing pada wajib pajak di KPP Pratama Karanganyar" diterima atau terbukti kebenarannya.

\section{Uji F}

Berdasarkan hasil analisis regresi linier berganda diperoleh nilai $F$ hitung sebesar 19,357 dengan $p$ value $(0,000)<0,05$ berarti model regresi linier berganda dinyatakan tepat (fit) dalam memprediksi pengaruh

\section{Uji Koefisien Determinasi}

Berdasarkan analisis regresi linier berganda diketahui bahwa besarnya nilai koefisien determinasi Adjusted $R^{2}$ adalah 0,271 artinya sumbangan pengaruh kualitas sistem informasi dan kualitas informasi terhadap kepuasan pengguna sistem e-filing adalah sebesar $27,1 \%$ sisanya sebesar $72,9 \%$ dijelaskan variabel lain yang tidak diteliti. Hasil uji koefisien determinasi disajikan seperti tabel

Hasil penelitian ini menunjukkan bahwa kualitas sistem informasi berpengaruh signifikan terhadap kepuasan pengguna sistem e-filing pada Kantor Pelayanan Pajak Pratama Karanganyar. Implikasi dari hasil temuan ini bahwa peningkatan kualitas sistem informasi akan mempengaruhi peningkatan kepuasan pengguna sistem $e$-filing pada Kantor Pelayanan Pajak (KPP) Pratama Karanganyar. Temuan ini mengindikasikan bahwa dengan persepsi yang baik mengenai kualitas sistem informasi, maka para wajib pajak khususnya dalam hal ini wajib pajak orang pribadi akan memperoleh manfaat selama menggunakan aplikasi e-filing. Wajib pajak yang merasa puas dikarenakan aplikasi e-filing memiliki kualitas sistem yang baik, seperti kemudahan penggunaan, sistem dapat diakses dengan mudah da cepat, sistem tahan dari kerusakan, dan adanya jaminan keamanan data bagi pengguna. Dengan demikian kesuksesan penerapan sistem e-filing ditentukan dari semakin puasnya para pengguna sistem 
dan diantaranya disebabkan karena sistem e-filing memiliki kualitas yang baik.

Hasil penelitian ini mendukung penelitian yang pernah dilakukan oleh Istianingsih \& Utami (2009); Purwaningsih (2010); Alhendawi \& Baharudin (2013); Raminda \& Ardini (2014); Fendini dkk (2014); Djuhono Tan dkk (2015); Setyo \& Rahmawati (2015); Sharabati et al (2015); Kartika dkk (2016) bahwa peningkatan kualitas sistem informasi akan mempengaruhi peningkatan kepuasan pengguna sistem informasi. Apabila kualitas sistem informasi semakin baik, akan meningkatkan kepuasan pengguna sistem.

Hasil penelitian ini menunjukkan bahwa kualitas informasi berpengaruh signifikan terhadap kepuasan pengguna sistem e-filing pada Kantor Pelayanan Pajak Pratama Karanganyar. Implikasi dari hasil temuan ini bahwa peningkatan kualitas informasi akan mempengaruhi peningkatan kepuasan pengguna sistem e-filing pada Kantor Pelayanan Pajak (KPP) Pratama Karanganyar. Temuan ini mengindikasikan bahwa dengan persepsi yang baik mengenai kualitas informasi, ditunjukkan dari pengalaman selama menggunakan aplikasi e-filing mampu memberikan informasi sesuai dengan harapan wajib pajak. Kualitas informasi yang diberikan oleh aplikasi $e$-filing dapat dinilai dari relevansi, keakuratan, ketepatwaktuan dan penyajian output yang mudah dipahami.

Hasil penelitian ini mendukung penelitian yang pernah dilakukan oleh Istianingsih \& Utami (2009); Purwaningsih (2010); Alhendawi \& Baharudin (2013); Raminda \& Ardini (2014); Fendini dkk (2014); Djuhono Tan dkk (2015); Setyo \& Rahmawati (2015); Sharabati et al (2015); Kartika dkk (2016) bahwa peningkatan kualitas informasi akan mempengaruhi peningkatan kepuasan pengguna sistem informasi. Apabila kualitas informasi semakin baik, akan meningkatkan kepuasan pengguna sistem.

Berdasarkan hasil penelitian ini memberikan implikasi stratejik bagi KPP Pratama Karanganyar, bahwa peningkatan kepuasan pengguna sistem $e$-filing dapat dicapai melalui peningkatan kualitas sistem informasi dan kualitas informasi. Untuk memaksimalkan pelayanan bagi WP maka kualitas sistem $e$-filing perlu mendapat pengawasan yang lebih baik lagi. Alternatif yang dapat dilakukan yaitu dengan selalu menjaga stabilitas penyimpanan data wajib pajak terutama mengenai berkas atau data storage, melakukan up date terhadap perangkat-perangkat keras (hardware). Direktorat Jenderal Pajak (DJP) khususnya KPP
Pratama Karanganyar disarankan untuk melakukan evaluasi terhadap kinerja sistem dan memperbaiki kekurangan-kekurangan terhadap implementasi sistem e-filing.

\section{Simpulan}

Hasil pengujian setiap hipotesis menunjukkan bahwa kualitas sistem informasi berpengaruh signifikan terhadap kepuasan pengguna sistem $e$-filing pada Kantor Pelayanan Pajak Pratama Karanganyar. Kualitas informasi berpengaruh signifikan terhadap kepuasan pengguna sistem e-filing pada Kantor Pelayanan Pajak Pratama Karanganyar.

Berdasarkan hasil temuan penelitian ini mengindikasikan bahwa WP yang merasa puas dikarenakan WP merasa terpenuhi atas kebutuhan informasinya di mana aplikasi $e$-filing yang digunakan memiliki kualitas sistem informasi dan kualitas informasi yang baik. Implikasi dari temuan ini, untuk memaksimalkan kepuasan pengguna sistem e-filing maka peningkatan kualitas sistem informasi dan kualitas informasi pada Kantor Pelayanan Pajak (KPP) Pratama Karanganyar wajib dilakukan

\section{Referensi}

[1] Alhendawi, K.M. and Baharudin, A.S., 2013, "The Mediating Role of Web User Satisfaction on Information Quality, Service Quality and the Effectiveness of Web-based Information System", Journal of Convergence Information Technology (JCIT), Vol. 8 (1), July, pp. 29-40.

[2] Arikunto, Suharsimi, 2006, Prosedur Penelitian, Edisi Revisi VI, Rineka Cipta, Jakarta.

[3] Davis, F.D., 1989, "Perceived Usefulness, Perceived Ease of Use, and User Acceptance of Information Technology", MIS Quarterly. September, pp.319- 340

[4] DeLone, W.H. dan McLean, E.R., 1992, Information System Success: The Quest for the Dependent Variable, Information System Research.

1. , 2003, The DeLone and McLea Model of Information Systems Success: A Ten Year Update, Journal of Management Information System/Spring, Vol. 19 (4).pp. 9-30.

[5] Fendini, D.S., Kertahadi, dan Riyadi, 2014, "Pengaruh Kualitas Sistem dan Kualitas Informasi terhadap Kepuasan Pengguna (Survei 
pada Karyawan Pengguna Aplikasi Pelayanan Pelanggan Terpusat (AP2T) di PT. PLN (Persero) Area Malang)", Jurnal Penelitian, Fakultas Ilmu Administrasi Universitas Brawijaya Malang, Hal. 1-11.

[6] Istianingsih dan Utami, W., 2009, "Pengaruh Kepuasan Pengguna Sistem Informasi terhadap Kinerja Individu (Studi Empiris pada Pengguna Paket Program Aplikasi Sistem Informasi Akuntansi di Indonesia)", Hal. 1-47. (www.multiparadigma.lecture.ub.ac.id).

[7] Kartika, N.D., Anton, dan Adnanti, W.A., 2016, "Analisis Kualitas Sistem Informasi, Perceived Usefulness dan Kualitas Informasi terhadap Kepuasan End User Software Akuntansi”, Simposium Nasional Akuntansi XIX-Lampung 2016, Hal. 1-21.

[8] Keputusan Menteri Pendayagunaan Aparatur Negara Nomor: KEP/25/M.PAN/2/ 2004 tentang Pedoman Umum Penyusunan Indeks Kepuasan Masyarakat Unit Pelayanan Instansi Pemerintah.

[9] Kotler, Philip. 2001, Manajemen Pemasaran, Analisis, Perencanaan, Implementasi dan Kontrol, Prehalindo, Jakarta.

[10] Purwaningsih, Susanti, 2010, “Analisis Kesuksesan Penerapan Sistem Informasi Pada Sistem Informasi Pelayanan Terpadu (SIPT) Online (Studi Pada PT Jamsostek (Persero))", Jurnal Aset, Vol. 12 (2), Hal. 181-189.

[11] Radityo, D. dan Zulaikha, "Pengujian Model DeLone and McLean dalam Pengembangan Sistem Informasi Manajemen (Kajian Sebuah Kasus)", Simposium Nasional Akuntansi X, Unhas Makassar 26-28 uJuli 2007, Hal. 1-25.

[12]Rahayu, Siti Kurnia, 2010, Perpajakan Indonesia, Konsep dan Aspek Formal, Graha Ilmu, Yogyakarta.

[13] Raminda, A.L.N. dan Ardini, L, 2014, "Pengaruh Kualitas Sistem, Kualitas Informasi dan Kepuasan Pengguna Accurate terhadap Kinerja Individu", Jurnal Ilmu \& Riset Akuntansi, Vol. 3 (9), Hal. 1-15.

[14] Setyo, D.B. dan Rahmawati, D.A., 2015, "Pengaruh Kualitas Informasi dan Kualitas Sistem Informasi terhadap Kepuasan serta Kinerja Pengguna Sistem Informasi”, Efektif Jurnal Bisnis dan Ekonomi, Vol. 6 (1), Juni , Hal. 47-59.
[15] Sharabati, M.M.N., Sulaiman, A. and Salleh, N.A.M., 2015, "End User Satisfaction and Individual Performance Assessments in eProcurement Systems", International Journal of Computer Theory and Engineering, Vol. 7 (6), December, pp. 503-509.

Website :

http://www.pajak.go.id/e-filing. e-Filing, Diakses: Minggu, 18 Nopember 2012 - 16:59 